\title{
Use of Björk-Shiley tilting disc prosthesis in valved conduits for right ventricular outflow reconstruction
}

\author{
T. B. Cartmill, J. M. Celermajer, D. S. Stuckey, J. D. Bowdler, D. C. Johnson, and R. E. \\ Hawker \\ From The Adolph Basser Institute of Cardiology, The Royal Alexandra Hospital for Children, Sydney, \\ Australia
}

Valved conduits made by incorporating Björk-Shiley tilting disc valve prostheses in woven 'dacron' arterial grafts have been used to bridge discontinuity between the right ventricle and the distal pulmonary arteries in 9 patients.

Age at operation varied between I2 days and I2 years. Five patients had persistent truncus arteriosus, 3 had pulmonary atresia, and I had d-transposition of the great arteries with ventricular septal defect and subpulmonary stenosis.

The only deaths have been in 2 desperately ill infants under 3 months of age. Survivors include a 2-monthold infant with truncus arteriosus.

Clinically the reconstructions continue to function satisfactorily after follow-up periods of up to I8 months, without identifiable evidence of valve dysfunction or pulmonary embolism.

The use of valved conduits to bridge discontinuities between the right ventricle (RV) and pulmonary arteries (Arai et al., 1965; Rastelli et al., 1965) has made possible surgical repair of various complex cardiac malformations, including pulmonary atresia, transposition of the great arteries with ventricular septal defect and subpulmonary stenosis, and truncus arteriosus. Allografts of the ascending aorta, incorporating the aortic valve and the anterior leaflet of the mitral valve, have most commonly been used as conduits, though imperfections of these grafts have led to the use of composite grafts of synthetic material incorporating a variety of valve mechanisms (Kouchoukos et al., 1971; Miki, Tatemichi, and Noguchi, 1971).

In 1971 we began using the Björk-Shiley tilting disc aortic valve prosthesis ${ }^{1}$ incorporated in 'dacron'2 vascular grafts ${ }^{3}$ to establish right ventricle to pulmonary artery continuity in such patients, a method also used by Cooley and his associates (in discussion of Fernandez et al., 1972).

Received 2 April 1974.

${ }_{1}$ Shiley Laboratories, Inc., Santa Ana, California, U.S.A.

${ }^{2}$ E.I. du Pont de Nemours Co., Inc.

${ }^{3}$ DeBakey Woven Dacron Graft, U.S.C.I. No. 6010, United States Catheter \& Instrument Corp., Glen Falls, New York, U.S.A.
This communication reports our initial experience in 9 patients.

\section{Clinical material}

Between I3 March 197I and I9 April 1973, 9 patients underwent corrective surgery using valved conduits (see Table).

Three infants, aged 12 days to 3 months, underwent primary correction of truncus arteriosus and 2 other patients, aged 4 and 5 years, underwent repair of truncus arteriosus after preliminary pulmonary artery banding. Three children, aged 2 to 12 years had repair of pulmonary atresia with ventricular septal defect and preliminary systemic to pulmonary artery shunts. One boy, aged 4 years, underwent repair of transposition of the great arteries with ventricular septal defect and subpulmonary stenosis.

\section{Technique}

Operation was performed using hypothermia induced by core cooling with a pump oxygenator and complete circulatory arrest, according to principles previously described (Cartmill, Overton, and Celermajer, 1973b; Cartmill et al., 1973a). In 3 patients the vena cavae were cannulated, allowing early cardiopulmonary bypass to be restarted during the final minutes of the repair.

During the period of core cooling, a Bjork-Shiley tilting disc prosthesis was fixed within a suitable woven 
TABLE

\begin{tabular}{|c|c|c|c|c|c|c|c|}
\hline $\begin{array}{l}\text { Case } \\
\text { No. }\end{array}$ & $\begin{array}{l}\text { Age } \\
\text { at } \\
\text { operation }\end{array}$ & $\begin{array}{l}\text { Weight } \\
(\mathrm{kg}) \\
\text { at } \\
\text { operation }\end{array}$ & Diagnosis & $\begin{array}{l}\text { Date } \\
\text { of } \\
\text { operation }\end{array}$ & $\begin{array}{l}\text { Graft } \\
\text { size } \\
\text { and type }\end{array}$ & $\begin{array}{l}\text { Valve } \\
\text { size } \\
(m m)\end{array}$ & Result \\
\hline $\mathbf{I}$ & $2 \mathrm{mth}$ & $3 \cdot 8$ & Truncus - type I & 2.1.73 & $\begin{array}{l}\text { I9 mm; } \\
\text { straight }\end{array}$ & 17 & Well $6 \mathrm{mth}$ later \\
\hline 2 & $3 \mathrm{mth}$ & $3 \cdot 8$ & Truncus - type 2 & 31.2 .73 & $\begin{array}{l}16 \mathrm{~mm} \text {; } \\
\text { straight }\end{array}$ & 17 & $\begin{array}{l}\text { Ventricular fibrillation } \\
\text { before surgery - no } \\
\text { effective cardiac } \\
\text { action after surgery }\end{array}$ \\
\hline 3 & $12 \mathrm{dy}$ & $3 \cdot 6$ & Truncus - type 2 & $20.3 \cdot 73$ & $\begin{array}{l}16 \mathrm{~mm} ; \\
\text { straight }\end{array}$ & 17 & $\begin{array}{l}\text { Moribund preopera- } \\
\text { tively; died I hour } \\
\text { postoperatively }\end{array}$ \\
\hline 4 & $5 \mathrm{yr}$ & $16 \cdot 6$ & $\begin{array}{l}\text { Truncus - type } 2 \text {, } \\
\text { bilateral pulmonary } \\
\text { artery banding }\end{array}$ & I3.6.72 & $\begin{array}{l}23 \mathrm{~mm} \text {; } \\
\text { bifurcation }\end{array}$ & 21 & Well I year later \\
\hline 5 & $4 \mathrm{yr}$ & $8 \cdot 9$ & $\begin{array}{l}\text { Truncus - type } I \text {, } \\
\text { main pulmonary } \\
\text { artery banding }\end{array}$ & 21.10 .72 & $\begin{array}{l}20 \mathrm{~mm} ; \\
\text { straight }\end{array}$ & 19 & Well ro months later \\
\hline 6 & $12 \mathrm{yr}$ & $33 \cdot 7$ & $\begin{array}{l}\text { Pulmonary atresia, } \\
\text { Blalock shunt }\end{array}$ & 7.12 .71 & $\begin{array}{l}22 \mathrm{~mm} \text {; } \\
\text { straight }\end{array}$ & 21 & Well I $\frac{1}{2}$ years later \\
\hline 7 & $2 \mathrm{yr}$ & $8 \cdot 6$ & $\begin{array}{l}\text { Pulmonary atresia, } \\
\text { Waterston shunt }\end{array}$ & 13.3 .71 & $\begin{array}{l}19 \mathrm{~mm} \text {; } \\
\text { bifurcation }\end{array}$ & 19 & Well 4 months later \\
\hline 8 & IO $\mathrm{yr}$ & $23 \cdot 0$ & $\begin{array}{l}\text { Pulmonary atresia, } \\
\text { Waterston shunt }\end{array}$ & $22.5 \cdot 73$ & $\begin{array}{l}20 \mathrm{~mm} ; \\
\text { straight }\end{array}$ & $2 \mathrm{I}$ & Well 2 months later \\
\hline 9 & $4 \mathrm{yr}$ & $14 \cdot 0$ & $\begin{array}{l}\text { Transposition of great } \\
\text { arteries ventricular } \\
\text { septal defect, } \\
\text { subpulmonary stenosis }\end{array}$ & I9.4.73 & $\begin{array}{l}20 \mathrm{~mm} ; \\
\text { straight }\end{array}$ & $2 \mathrm{I}$ & Well 3 months later \\
\hline
\end{tabular}

'dacron' vascular graft, either with interrupted or running sutures, or by removing the fabric sewing ring from the valve and locating the metallic valve ring within the graft by numerous strong synthetic suture ligatures tied about the outside of the graft. Seven straight tubular grafts ranging from 16 to $22 \mathrm{~mm}$ in diameter and two aortic bifurcation grafts were used (see Table). The valve prostheses ranged from $17 \mathrm{~mm}$ to $21 \mathrm{~mm}$, and valves with pyrolytic carbon discs were used in all except one of the patients.

Repair was performed during a period of circulatory arrest which ranged from 42 to 62 minutes at nasopharyngeal temperatures of 17 to $18^{\circ} \mathrm{C}$.

A small area of the right ventricular wall was removed, avoding major coronary artery branches. The ventricular septal defect was repaired with a heavy 'dacron' patch' directing left ventricular blood to the overriding or transposed aorta or truncus.

Straight conduits were cut to length and anastomosed to the main pulmonary artery distally when it was present, or to the confluence of the right and left pulmonary arteries, with the grafts spiralling either to right or left of the ascending aorta.

In 2 patients the legs of the bifurcated grafts had to be anastomosed separately to each pulmonary artery, leaving the crotch of the graft astride the truncus or ascending aorta.

The proximal end of the graft was then cut obliquely to a length allowing the conduit to assume an easy curve after being sutured to the right ventricle and locating ${ }^{1}$ Cooley Graft. Meadox Chemical, Oakland, N.J., U.S.A. the prosthetic valve ring so that its rigidity would prevent compression or distortion of the conduit after sternal closure.

Anticoagulants were not used after repair with this valved conduit.

\section{Results}

\section{Mortality}

Two of the three infants aged 3 months or less did not survive operation. The youngest was moribund, anuric, and acidotic before cardiac catheterization; the other suffered ventricular fibrillation before thoracotomy, and effective cardiac action could not be re-established either before cannulation or after completion of the repair. The remaining 7 patients have survived operation and remain well $\mathrm{I}$ to $\mathrm{I} 8$ months after operation (see Table).

\section{Morbidity}

No specific complications peculiar to this operation have been identified. Survivors developed moderate fluid retention after operation, but this responded to therapy with digoxin and frusemide.

\section{Late results}

There has been no clinical evidence of valve dys- 
function in any of the survivors and pulmonary embolism has not been recognized. Elective postoperative cardiac catheterization has not yet been performed and there has been no clinical indication for restudy.

\section{Discussion}

Although large series of successful valved conduit operations using ascending aorta allografts have been reported (McGoon, Wallace, and Danielson, 1973), these grafts have several potential disadvantages. These include difficulties of procurement, sterilization, and storage, early graft wall calcification, the likelihood of late valve failure and various technical difficulties with kinking, compression, or inconvenient shapes or sizes of grafts. Composite grafts of synthetic fabric tubing incorporating tissue valves have overcome the difficulty of graft wall calcification, are technically versatile, and are free from thromboembolic complications. However uncertainty remains about long-term tissue valve durability.

The use of a Björk-Shiley tilting disc prosthesis with its excellent ratio of effective flow orifice to external diameter, central flow characteristics, and low inertia disc, appears to offer near perfect haemodynamic function. The very low profile of this valve also allows free disc motion even in the smallest patient. We consider that the durability of this valve outweighs the risk of thromboembolism, which has been negligible for aortic valve replacement with Björk-Shiley tilting disc prostheses (Fernandez et al., 1972; Lepley et al., 1973).

The recent commercial availability of a prefabricated valved graft ${ }^{1}$ will make the present techniques even easier to apply, though occasional special technical problems may still warrant the construction of bespoke grafts, particularly when a bifurcated or other unusually shaped graft is needed.

Further clinical observation and serial cardiac catheterization and angiocardiographic studies will be necessary for long-term evaluation of graft and valve function, and to investigate potential evaluation of pulmonary vascular resistance consequent to possible repeated pulmonary embolism.

${ }^{1}$ Shiley Graft Valve Prosthesis, Shiley Laboratories, Inc., Santa Ana, California, U.S.A.
Those infants in whom only the smallest sized valves and grafts can be used will probably require later revision. This is a disadvantage common to all conduit operations in infancy.

Meanwhile these satisfactory clinical results have encouraged us to continue to use this easily obtainable and versatile form of valved conduit.

\section{References}

Arai, T., Tsuzuki, Y., Nogi, M., Kurashige, K., Koyanagi, H., Nishida, H., Ikeda, Y., and Ichikawa, M. (I966). Experimental study on bypass between right ventricle and pulmonary artery and left ventricle and aorta by means of a homograft with valve. Bulletin of the Heart Institute, fapan, 9, 49.

Cartmill, T. B., Barr, P. A., Overton, J. H., and Celermajer, J. M. (1973a). Repair of cyanotic heart disease in infancy with hypothermic perfusion and circulatory arrest. Singapore Medical fournal, 14, 254.

Cartmill, T. B., Overton, J. H., and Celermajer, J. M. (1973b). Deep hypothermia and perfusion in infancy. In Heart Disease in Infancy, pp. 2 and 45 . Ed. by B. G. Barratt-Boyes, J. M. Neutze, and E. A. Harris. Churchill Livingstone, Edinburgh and London.

Fernandez, J., Maranhao, V., Gooch, A. S., Morse, D., and Nichols, H. T. (1972). The Björk-Shiley prosthesis: a significant advance in aortic valve replacement. Annals of Thoracic Surgery, 14, 527.

Kouchoukos, N. T., Barcia, A., Bargeron, L. M., and Kirklin, J. W. (1971). Surgical treatment of congenital pulmonary atresia with ventricular septal defect. Fournal of Thoracic and Cardiovascular Surgery, 6r, 70.

Lepley, D., Jr., Reuben, C. F., Flemma, R. J., Huston, J. H., Manley, J. C., Hoffman, J. F., and Tector, A. J. (1973). Experience with the Björk-Shiley prosthetic valve. Circulation, 48, Suppl. 3, 51 .

McGoon, D. C., Wallace, R. B., and Danielson, G. K. (1973). The Rastelli operation: its indications and results. fournal of Thoracic and Cardiovascular Surgery, 66, 65.

Miki, S., Tatemichi, K., and Noguchi, K. (1971). Reconstruction of pulmonary valve using autologous fascia lata valve mounted on a support frame. Fapanese fournal of Thoracic Surgery, 24, 533.

Rastelli, G. C., Ongley, P. A., Davis, G. D., and Kirklin, J. W. (1965). Surgical repair for pulmonary valve atresia with coronary-pulmonary artery fistula: report of a case. Mayo Clinic Proceedings, 40, 521.

\section{Addendum}

All survivors continue to do well in June 1974.

Requests for reprints to T. B. Cartmill, F.R.A.C.S., The Adolph Basser Institute of Cardiology, The Royal Alexandra Hospital for Children, Camperdown 2050, Sydney, New South Wales, Australia. 